\title{
Can diaphragm excursion predict prognosis in patients with severe pneumonia?
}

\author{
Aslıhan GÜRÜN \\ $\operatorname{KAYA}(I D)$ \\ Elvan Burak VERDi(ID) \\ Sema Nur SÜSLÜ(ID) \\ Miraç ÖZ(ID) \\ Serhat EROL $(I D)$ \\ Fatma ÇiFTÇi $(I D)$ \\ Aydın ÇiLEDAĞ(ID) \\ Akın KAYA(ID)
}

Ankara University Faculty of Medicine, Department of Chest Disease, Ankara, Turkey

Ankara Üniversitesi Tıp Fakültesi, Göğüs Hastalıkları Anabilim Dalı, Ankara, Türkiye

\begin{abstract}
Can diaphragm excursion predict prognosis in patients with severe pneumonia?

Introduction: Although thorax ultrasound has been used to diagnose pneumonia in recent years, the role of ultrasonic diaphragm evaluation in the prognosis of pneumonia is unknown. This study aimed to assess the impact of diaphragmatic excursion (Dex) measured by ultrasound on the prognosis of severe pneumonia in critical care patients.
\end{abstract}

Materials and Methods: We prospectively recruited patients with severe pneumonia who were admitted to the intensive care unit (ICU) between January 2019 and July 2021. Patients' Dex values, vital signs, clinical features, laboratory parameters, APACHE-II scores on the first admission day of ICU, mortality and respiratory support status at follow-up were recorded.

Results: There were 39 patients enrolled in the study. Mean Dex of the study patients was $30.66 \pm 12.17 \mathrm{~mm}$. Mean Dex was significantly lower in deceased patients than survivors $(18.37 \pm 8.12$ vs $34.90 \pm 10.36 p<0.001)$. Dex was lower in patients who required invasive mechanical ventilation than those not $(24.90 \pm 10.93$ vs $34.26 \pm 11.70, p=0.017)$. The cut-off value of Dex was found $19.0 \mathrm{~mm}$ for significantly predicted ( $p \leq 0.001$ ) survival with the sensitivity of $96.6 \%$ and specificity of $70 \%$. Among the study group, diaphragm excursion was negatively correlated with APACHE-II score $(r=-0.688, p \leq$ $0.001)$ and respiratory rate $(r=-0.531, p=0.001)$.

Conclusion: Dex measured on the day of ICU admission can be used to evaluate the prognosis of patients with severe pneumonia.

Key words: Pneumonia; diaphragm ultrasound; diaphragm excursion

ÖZ

Diyafram ekskürsüyonu ağır pnömoni hastalarında prognozu öngörebilir mi?

Giriş: Son yıllarda pnömoni tanısında toraks ultrasonu kullanılmasına rağmen, diyaframın ultrasonik değerlendirmesinin pnömoni prognozundaki rolü bilin- 
memektedir. Bu çalışmada, yoğun bakım hastalarında ultrasonla ölçülen diyafragma ekskürsüyonu (Dex) ağır pnömoni olgularının prognozu üzerindeki etkisinin değerlendirilmesi amaçlanmıştır.

Materyal ve Metod: Çalışmamıza, Ocak 2019 ile Temmuz 2021 arasında yoğun bakım ünitesine (YBü) yatırılan ağır pnömonili hastalar prospektif olarak dahil edildi. Hastaların YBÜ'ye ilk kabul günündeki Dex değerleri, vital bulguları, klinik özellikleri, laboratuvar parametreleri, APACHE-II skorları, takiplerde ise mortalite ve solunum destek durumları kaydedildi.

Bulgular: Çalışmaya 39 hasta dahil edildi. Hastaların ortalama Dex değeri 30,66 $\pm 12,17 \mathrm{~mm}$ idi. Ortalama Dex, ölen hastalarda hayatta kalanlardan daha düşüktü (18,37 \pm 8,12'ye vs 34,90 $\pm 10,36$ p<0,001). Dex, invaziv mekanik ventilasyon (IMV) gerektiren

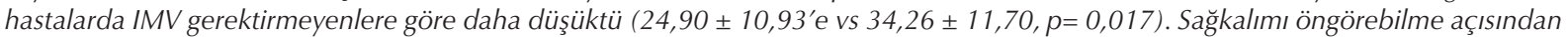
Dex için sınır değer, \%96,6 duyarlılık ve \%70 özgüllük ile $(p \leq 0,001) 19.0 \mathrm{~mm}$ bulundu. Hastaların Dex değerleri ile APACHE-Il skoru $(r=-0,688, p \leq 0,001)$, solunum sayısı $(r=-0,531, p=0,001)$ arasında negatif yönde korelasyon saptandı.

Sonuç: Çalışma sonuçlarımız YBÜ yatış gününde ölçülen Dex değerinin, ağır pnömonisi olan hastaların prognozunu değerlendirmede kullanılabileceğini düşündürmektedir.

Anahtar kelimeler: Pnömoni; diyafram ultrasonu; diyafram ekskürsüyon

\section{INTRODUCTION}

Pneumonia is the common reason for intensive care unit (ICU) admissions worldwide. Additionally, it is the prevalent secondary infection acquired by critically ill patients. Severe pneumonia is the most common cause of septic shock, often requires respiratory support therapy, and is associated with a high mortality rate (1). Therefore, early recognition of severe disease is crucial for improved prognosis. Various scoring systems have been described to assess severity of the disease. Furthermore, serum biomarkers help diagnose and predict prognosis in clinical practice (1-3).

In recent years, thoracic ultrasound has gained popularity with easy imaging of the lung, pleura and diaphragm in an efficient, cost-effective, and safe manner. It is widely used to diagnose pleural fluid, atelectasis, pneumonia and pneumothorax with good sensitivity and specificity. Diaphragmatic ultrasound is also helpful for the evaluation of diaphragmatic function and its movement. It also provides information about vital capacity, work of breathing, diaphragm contractile activity (4-7).

Diaphragm ultrasound has been used to predict the success of weaning from mechanical ventilation and assess respiratory effort. Additionally, sonographic diaphragm assessment can be applied to recognize diaphragmatic fatigue after surgery (8). Although few studies show that diaphragm ultrasound can predict pneumonia severity in children (9), the effect on the severity of pneumonia in adult patients is not clearly known. This study aimed to assess the impact of diaphragmatic excursion (Dex) measured by ultrasound on the prognosis of severe pneumonia in critical care patients.

\section{MATERIALS and METHODS}

\section{Study Participants}

We conducted a prospective study at the ICU of Ankara University Faculty of Medicine Department of Chest Diseases between January 2019 and July 2021. All adult patients with severe pneumonia who were admitted to our ICU were considered eligible. The criteria for severe pneumonia was identified using the 2007 Infectious Diseases Society of America (IDSA)/ American Thoracic Society (ATS) (10) criteria include the following: (1) having $\geq 1$ of major criteria (invasive mechanical ventilation or septic shock requiring vasopressors); (2) having $\geq 3$ of the minor criteria (radiological multilobar infiltrates, increased respiratory rate $\geq 30$ breath $/ \mathrm{min}, \mathrm{PaO}_{2} / \mathrm{FiO}_{2} \leq 250 \mathrm{mmHg}$, confusion, increased blood urea nitrogen (BUN) $\geq 20 \mathrm{mg} / \mathrm{dL}$, decreased leukocyte count $<4000$ cells/ $\mathrm{mm}^{3}$, decreased platelet count $<100.000$ cells $/ \mathrm{mm}^{3}$, hypothermia $<36^{\circ} \mathrm{C}$, hypotension requiring excessive fluid resuscitation). Patients with a life-threatening condition requiring immediate intubation, being under invasive mechanical ventilation on ICU admission, neuromuscular disease, diaphragm paralysis, diaphragmatic hernia, chest wall abnormalities, recent cardiothoracic surgery and transferred from another critical care unit were excluded from the study. The study was approved by the Human Research Ethics Committee of Ankara University). Written informed consent was obtained from each patient or legal relative before enrolment in the study.

The patients' demographic features, comorbid diseases, the reason for ICU admission, APACHE-II score, baseline hemogram, biochemical and arterial blood analysis results were recorded in the first 24 hours of 
ICU admission. Additionally, during the study's follow-up time, patients' data about the state of respiratory support, if any, duration of ICU stay and state of mortality were collected.

\section{Diaphragm Ultrasound}

Diaphragm ultrasound was performed to assess Dex by the same trained pulmonologist to reduce inter-operator difference, using 2 to $5 \mathrm{MHz}$ phased array transducer at the bedside with a SonoSite M-Turbo (SonoSite Inc., Bothell, WA, USA). At supine position, the probe is placed via a subcostal approach in the mid-clavicular line below the right costal margin to obtain a good visualisation of the motion of the right hemidiaphragm on B-mode. After correct visualisation of the right hemidiaphragm by B-mode, M-mode is used to display the movement of the diaphragm. During inspiration, the dome of the diaphragm moves towards the ultrasound probe. The diaphragmatic excursion is measured during quiet breathing by placing callipers at the bottom and top of the diaphragmatic inspiratory and expiratory slope (Figure 1).

\section{Statistical Analysis}

Statistical analyses were performed using the IBM SPSS Statistics (Version 22.0. Armonk, NY: IBM Corp.). The variables were investigated using visual (histograms and probability plots) and analytical
(Kolmogorov-Smirnov/Shapiro-Wilk's test) methods to determine the normality of distribution. Normally distributed variables were presented as mean and SD, while non-normally distributed variables were presented as a median and interquartile range of $25^{\text {th }}-75^{\text {th }}$ percentiles $\left[\mathrm{IQR}_{25-75}\right]$. An unpaired Student's t-test and a Mann-Whitney $U$ test were used for the between-group comparison. The $\chi 2$ test or Fisher's exact test was used to compare categorical variables. Correlation coefficients and their significance were calculated using Pearson's tests. Receiveroperating characteristics (ROC) analysis was performed to quantify Dex on mortality using the area under the curve (AUC). P-value of $<0.05$ was considered statistically significant.

\section{RESULTS}

In the study period, 51 patients were admitted to the $\mathrm{ICU}$ with severe pneumonia. Following the exclusion of 12 patients, 39 patients were enrolled in the study flow chart of the study patients in Figure 2. Mean age of the study patients was $69.4 \pm 7.8$ years, and 17 of them were females. Baseline demographic and clinical features of study patients are given in Table 1.

All 39 patients had moderate to severe hypoxemia $\left(\mathrm{PaO}_{2}<60 \mathrm{mmHg}\right)$ when admitted to the ICU; nine of whom also had hypercapnia $\left(\mathrm{PaCO}_{2}>45 \mathrm{mmHg}\right)$. Within the first 24 hours of ICU admission, six

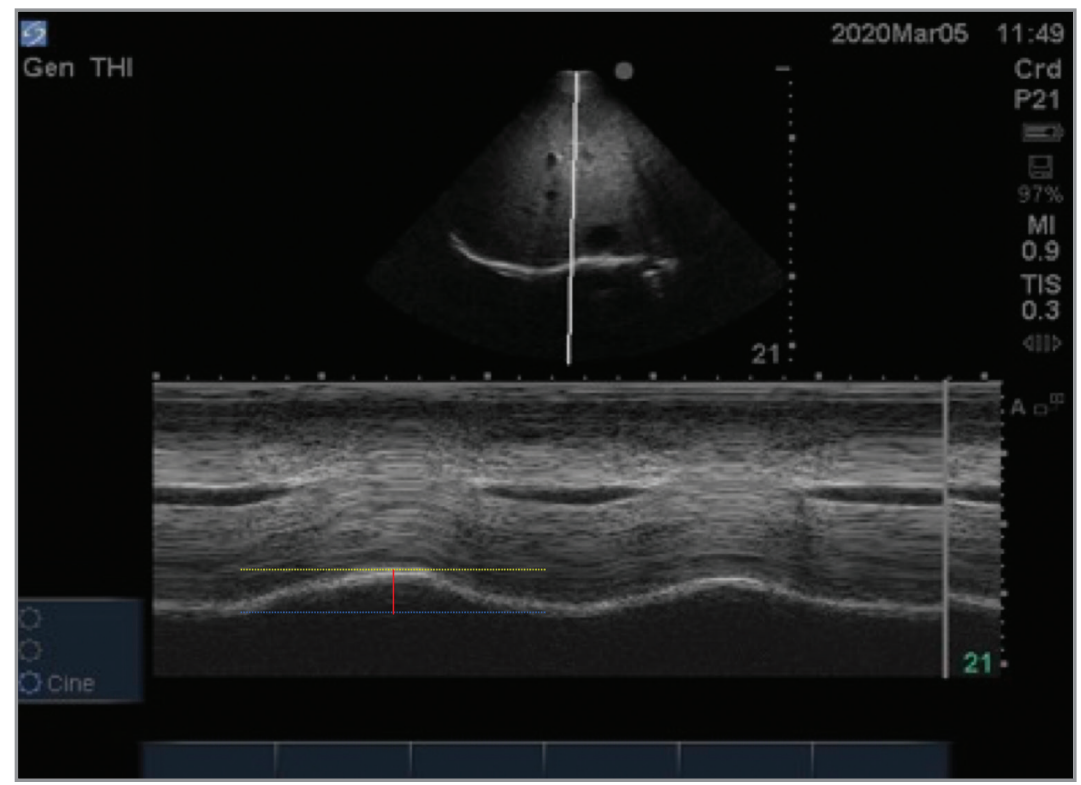

Figure 1. Measurement of Dex on M-mode. Red-line indicates the diaphragm excursion amplitude, yellow-line indicates the end-inspiration level of the diaphragm, blue-line indicates the end-expiration level of the diaphragm. 


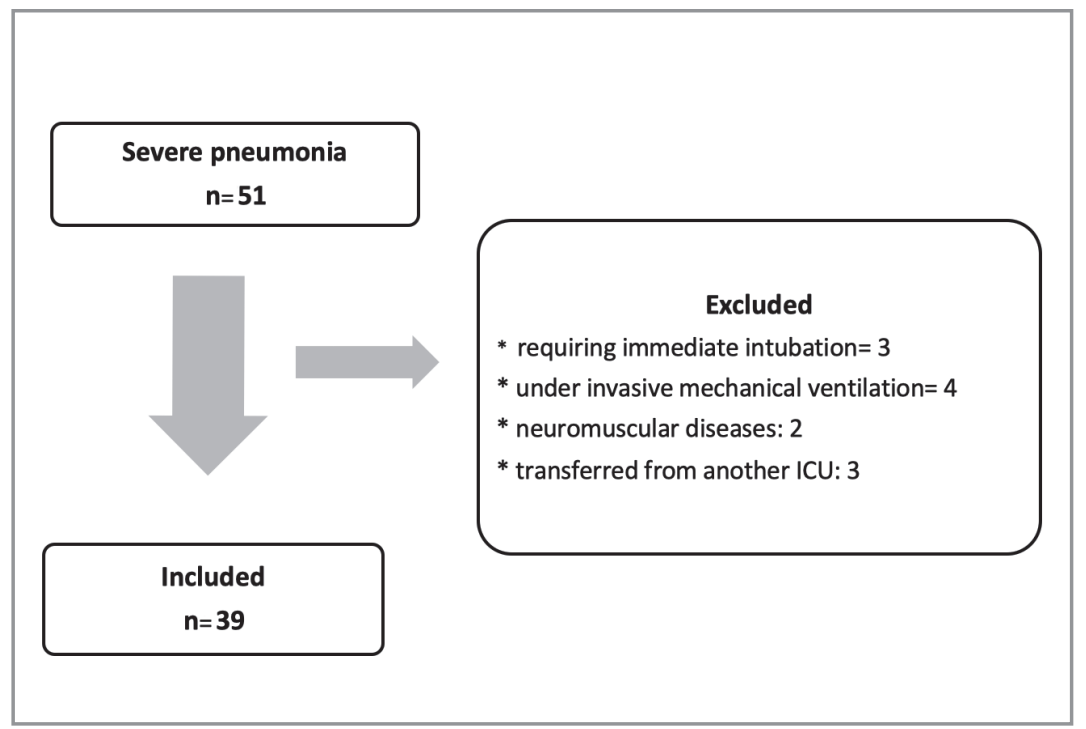

Figure 2. Flow-chart of the study patients.

patients required invasive mechanical ventilation (IMV), 11 patients received high flow nasal cannula oxygen (HFNC), and 13 patients received noninvasive mechanical ventilation (NIMV). The other nine patients received conventional oxygen therapy (COT). During follow-up in the ICU, 15 patients had required respiratory support escalation (COT escalation to HFNC/NIMV/IMV; HFNC/NIMV escalation to IMV). During ICU stay, 15 patients required IMV.

All of the 39 study patients required vasopressor therapy during ICU stay. There were nine deaths $(23.6 \%)$ (8 of under IMV, 1 of NIMV) during the ICU stay in this study, with a median survival time of 10 days $\left(\mathrm{IQR}_{25-75}: 7.0-14.5\right)$. Median length of ICU stay of the survivors was 12 days $\left(\mathrm{IQR}_{25-75}: 9.5-16.0\right)$.

Mean Dex of the study patients was $30.66 \pm 12.17$ $\mathrm{mm}$. Mean Dex was significantly lower in deceased patients than survivors $(18.37 \pm 8.12$ vs $34.90 \pm$ 10.36, $\mathrm{p}<0.001$ ). Additionally, Dex was lower in patients who required invasive mechanical ventilation than those who did not $(24.90 \pm 10.93$ vs 34.26 $\pm 11.70, p=0.017$ ).

The cut-off value of Dex was found $19.0 \mathrm{~mm}$ for significantly predicted $(p \leq 0.001)$ survival with the sensitivity of $96.6 \%$ and specificity of $70 \%$. For predicting survival, Dex's areas under ROC curves were AUC: $0.883,95 \%$ confidence interval: $0.759-1.00$ (Figure 3).

Baseline laboratory tests and clinical characteristics of the patients were compared to determine possible differences between patients with Dex $\geq 19 \mathrm{~mm}$ and $<19 \mathrm{~mm}$ (Table 2).

Among the study group, diaphragm excursion was negatively correlated with APACHE-II score $(r=$ $-0.688, p \leq 0.001)$, respiratory rate $(r=-0.531, p=$ 0.001 ) at the admission day to the ICU. Besides that, diaphragm excursion did not correlate with the length of ICU stay $(r=-0.075 ; p=0.649)$ (Figure 4).

\section{DISCUSSION}

The present study showed that Dex negatively correlated with APACHE-II score and respiratory rate in patients with severe pneumonia. Mean Dex was significantly lower in deceased patients than in those who survived, while it was also lower in patients who required IMV than those who did not. Additionally, we found the optimal cut-off value for Dex to predict mortality in ICU patients with severe pneumonia was $19 \mathrm{~mm}$ with a sensitivity of $96.6 \%$ and specificity of $70 \%$. As to our knowledge, this is the first study to evaluate the impact of Dex measured by ultrasound on the prognosis of critical care patients with severe pneumonia.

Diaphragm is the primary main inspiratory muscle of breathing and plays a pivotal role in pulmonary ventilation. Several techniques are available to evaluate the diaphragm functions and activity, such as chest X-ray, fluoroscopy, diaphragm EMG, computed tomography $(\mathrm{CT})$, pulmonary function tests. Beyond these techniques, ultrasonography has gained popularity in recent years, particularly in ICU, providing 


\section{Table 1. The baseline characteristics of study patients}

n (\%) mean \pm SD median [IQR25-75]

\begin{tabular}{|c|c|}
\hline Age (year) & $71.05 \pm 14.78$ \\
\hline Gender (male) & $25(64.1 \%)$ \\
\hline \multicolumn{2}{|l|}{ Comorbid disease } \\
\hline Hypertension & $25(64.1 \%)$ \\
\hline Diabetes mellitus & $13(33.3 \%)$ \\
\hline COPD & $19(48.7 \%)$ \\
\hline Asthma & $1(2.6 \%)$ \\
\hline Interstitial lung disease & $1(2.6 \%)$ \\
\hline Hearth failure & $16(41.0 \%)$ \\
\hline Atherosclerotic heart disease & $10(25.6 \%)$ \\
\hline Malignancy & $7(17.9 \%)$ \\
\hline APACHE-II score & $17.35 \pm 3.32$ \\
\hline Mean arterial blood pressure $(\mathrm{mmHg})$ & $96.01 \pm 12.12$ \\
\hline Pulse rate (beats per minute) & $97.20 \pm 27.72$ \\
\hline Respiratory rate (breaths per minute) & $24.97 \pm 6.00$ \\
\hline \multicolumn{2}{|l|}{ Basal laboratory tests } \\
\hline $\mathrm{PaO}_{2}(\mathrm{mmHg})$ & $53.04 \pm 5.84$ \\
\hline $\mathrm{PaCO}_{2}(\mathrm{mmHg})$ & $43.01 \pm 6.04$ \\
\hline $\mathrm{Hb}(\mathrm{g} / \mathrm{dL})$ & $11.38 \pm 2.22$ \\
\hline Leucocytes $\left(10^{3} / \mathrm{mm}^{3}\right)$ & $11.92 \pm 3.47$ \\
\hline Platelet $\left(10^{3} / \mathrm{mm}^{3}\right)$ & $227.27 \pm 60.81$ \\
\hline BUN (mg/dL) & $32[22-56]$ \\
\hline Creatinin (mg/dL) & $0.97[0.75-1.37]$ \\
\hline $\operatorname{ALT}(\mathrm{U} / \mathrm{L})$ & $18[13-37]$ \\
\hline AST (U/L) & $27[20-44]$ \\
\hline Albumin (g/L) & $31.33 \pm 5.89$ \\
\hline Protein (g/L) & $50.04 \pm 8.25$ \\
\hline Magnesium (mg/dL) & $2.12 \pm 0.42$ \\
\hline $\mathrm{Ca}(\mathrm{mg} / \mathrm{dL})$ & $8.53 \pm 0.61$ \\
\hline $\mathrm{Na}(\mathrm{mmol} / \mathrm{L})$ & $138.22 \pm 6.25$ \\
\hline $\mathrm{K}(\mathrm{mmol} / \mathrm{L})$ & $4.41 \pm 0.75$ \\
\hline
\end{tabular}

COPD: Chronic obstructive pulmonary disease, APACHE: The acute physiology and chronic health evaluation, PaO 2 : Partial arterial oxygen pressure; $\mathrm{PaCO}_{2}$ : Partial arterial carbondioxide pressure; Hb: Haemoglobin, BUN: Blood urea nitrogen, ALT: Alanine aminotransferase, AST: Aspartate aminotransferase, Ca: Calcium; Na: Sodium; K: potassium.

real-time imaging as a bedside applicable, noninvasive method $(11,12)$. To date, most of the studies about diaphragm ultrasound have focused on weaning from mechanical ventilation, postoperative diaphragm functions and diaphragm paralysis (8). Diaphragm excursion, diaphragm thickness and diaphragm thickness fraction were found to predict adverse outcomes, such as weaning failure, pro- longed mechanical ventilation, prolonged ICU stay, and increased mortality in critical care patients (5,6,13-15). Although diaphragm ultrasound parameters have been evaluated in COVID-19 pneumonia in a few studies $(4,16)$, no studies provide information about diaphragm ultrasound on the prognosis of pneumonia due to other infectious agents in critical care patients. 


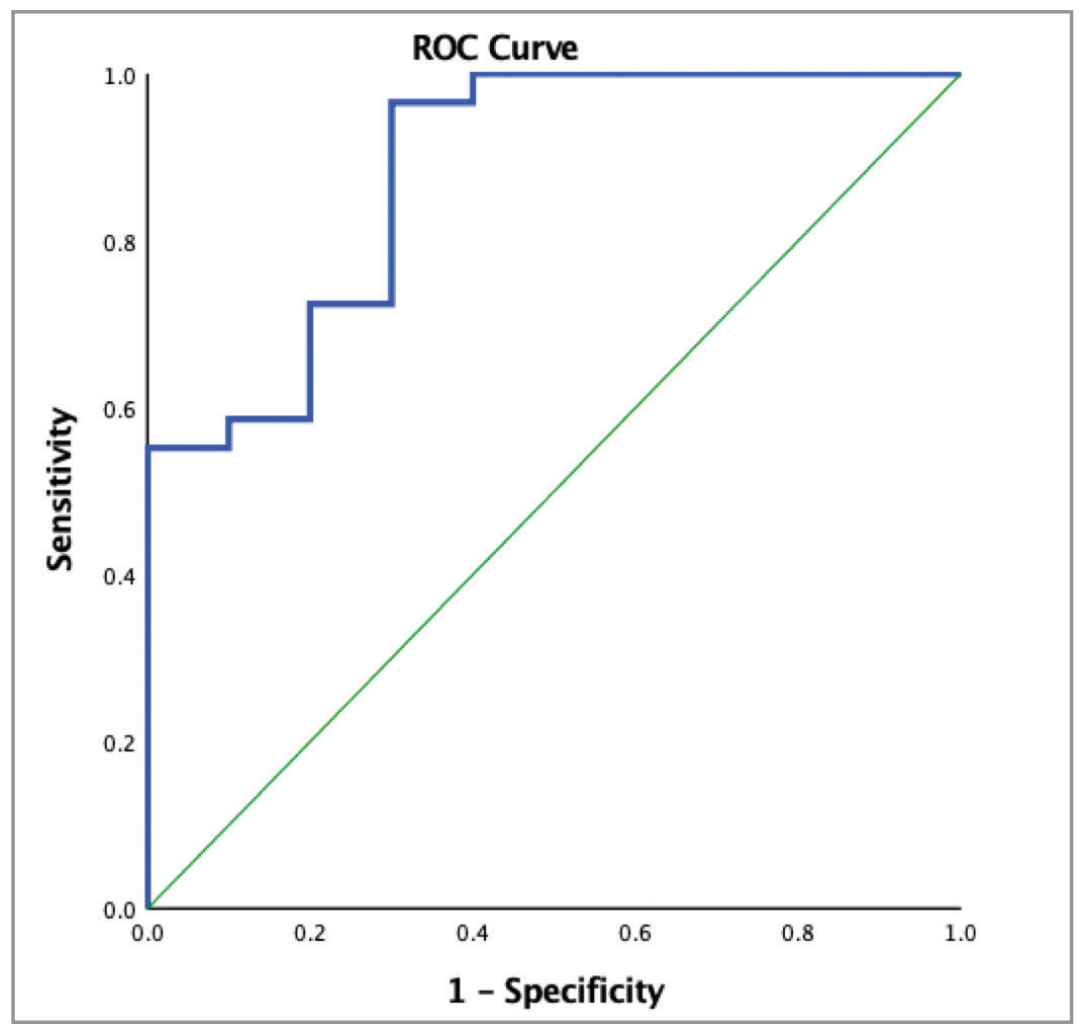

Figure 3. ROC curve analysis of Dex for predicting survival.

Despite recent advances in treatments and vaccines for both bacterial and viral agents, pneumonia remains the leading cause of ICU stay and death from infection. Furthermore, various studies suggest that respiratory failure, severe sepsis/septic shock, and comorbid conditions are at greater risk of poor prognosis $(17,18)$. Increased B-lines which are vertical hyperechoic artefacts arising from the pleural line; diminished of A-lines, which are reverberation artifacts of pleural line; tissue-like structure due to the loss of aeration of the lung; and pleural fluid can be found in thorax ultrasound in pneumonia $(7,19-21)$. The location and intensity of these findings provide information to assess the severity of pneumonia. Furthermore, different scores, including lung ultrasound findings and clinical/laboratory parameters have been suggested to diagnose and monitor pneumonia (19). A meta-analysis by Chavez et al. has described a clear advantage of using lung ultrasound over standard imaging for pneumonia with AUC 0.98 (95\% Cl: 0.98-0.99) (22). However, these studies have focused on lung ultrasound and parenchymal findings instead of diaphragm movement and strength.
The present study revealed that patients who died had lower Dex than survivors. In addition, Dex was negatively correlated with the APACHE-II score and the respiratory rate, which are the parameters that determine severity of pneumonia. Theoretically, a severe infectious/inflammatory process originating in localizations adjacent to the diaphragm can affect diaphragm mobility and strength directly by contiguity (23). In addition, decreased diaphragmatic functions may result from increased respiratory workload or atelectasis associated with pneumonia. Hypoxemia is one of the common features of pneumonia, and reduced oxygen transport to the diaphragm and other respiratory muscles may lead to respiratory muscle fatigue through possible mechanisms; increased minute ventilation and consequently the work of breathing, enhanced blood flow competition between respiratory and locomotor muscles, increased number of circulating metabolites such as lactate $(24,25)$. O'Leary and O'Halloran have shown that acute hypoxia is sufficient to weaken diaphragm peak force-generating capacity by $30 \%$ in a rat and suggested diaphragm dysfunction caused by acute-hypoxia could be an under-recognized by other factors contributing to diaphragm weakness in critical care 
Table 2. Comparing patients' characteristics between patients with a diaphragmatic excursion of $\geq 19 \mathrm{~mm}$ and $<19 \mathrm{~mm}$

\begin{tabular}{|c|c|c|c|}
\hline & $\begin{array}{c}\text { Patients with diaphragm } \\
\text { excursion }<19 \mathrm{~mm}(\mathrm{n}=8)\end{array}$ & $\begin{array}{l}\text { Patients with diaphragm } \\
\text { excursion } \geq 19 \mathrm{~mm}(n=31)\end{array}$ & $\mathbf{p}$ \\
\hline Age (year) & $79 \pm 14.92$ & $69.00 \pm 14.26$ & 0.118 \\
\hline Gender (male) & $4(50.0 \%)$ & $21(67.7 \%)$ & 0.424 \\
\hline \multicolumn{4}{|l|}{ Comorbid disease } \\
\hline Hypertension & $5(62.5 \%)$ & $20(64.5 \%)$ & 0.916 \\
\hline Diabetes mellitus & $1(12.5 \%)$ & $12(30.8 \%)$ & 0.229 \\
\hline COPD & $2(25 \%)$ & $17(54.8 \%)$ & 0.235 \\
\hline Asthma & 0 & $1(3.2 \%)$ & $>0.999$ \\
\hline Interstitial lung disease & 0 & $1(3.2 \%)$ & $>0.999$ \\
\hline Hearth failure & $6(75.0 \%)$ & $10(32.3 \%)$ & 0.045 \\
\hline Atherosclerotic heart disease & $2(25.0 \%)$ & $8(25.8 \%)$ & 0.999 \\
\hline Malignancy & $2(25.0 \%)$ & $5(16.1 \%)$ & 0.617 \\
\hline APACHE-II score & $21.62 \pm 2.61$ & $16.25 \pm 2.51$ & $<0.001$ \\
\hline Mean arterial blood pressure $(\mathrm{mmHg})$ & $91.00 \pm 12.18$ & $97.30 \pm 11.96$ & 0.193 \\
\hline Pulse rate (beats per minute) & $93.6 \pm 26.70$ & $98.12 \pm 28.33$ & 0.688 \\
\hline Respiratory rate (breaths per minute) & $30.25 \pm 8.76$ & $23.6 \pm 4.29$ & 0.072 \\
\hline \multicolumn{4}{|l|}{ Respiratory support during ICU stay } \\
\hline High flow nasal cannula & $3(37.5 \%)$ & $13(41.9 \%)$ & 0.815 \\
\hline Non-invasive ventilation & $4(50.0 \%)$ & $13(41.9 \%)$ & 0.670 \\
\hline Invasive ventilation & $6(75.0 \%)$ & $9(29.0 \%)$ & 0.037 \\
\hline Need for respiratory support escalation & $6(75.0 \%)$ & $9(29.0 \%)$ & 0.037 \\
\hline \multicolumn{4}{|l|}{ Basal laboratory tests } \\
\hline $\mathrm{PaO}_{2}(\mathrm{mmHg})$ & $49.16 \pm 6.84$ & $54.04 \pm 5.22$ & 0.033 \\
\hline $\mathrm{PaCO}_{2}(\mathrm{mmHg})$ & $48.36 \pm 6.21$ & $41.63 \pm 5.26$ & 0.003 \\
\hline $\mathrm{Hb}(\mathrm{g} / \mathrm{dL})$ & $10.60 \pm 0.93$ & $11.58 \pm 2.42$ & 0.269 \\
\hline Leucocytes $\left(10^{3} / \mathrm{mm}^{3}\right)$ & $13.09 \pm 2.78$ & $11.62 \pm 3.61$ & 0.719 \\
\hline Platelet $\left(10^{3} / \mathrm{mm}^{3}\right)$ & $215.87 \pm 69.23$ & $230.22 \pm 59.35$ & 0.714 \\
\hline BUN (mg/dL) & $51[27.3-81.0]$ & $30[20-49]$ & 0.065 \\
\hline Creatinin (mg/dL) & $1.20[0.84-1.66]$ & $0.95[0.75-1.29]$ & 0.169 \\
\hline $\operatorname{ALT}(\mathrm{U} / \mathrm{L})$ & $20.0[13.0-37.0]$ & $17.50[13.25-23.75]$ & 0.553 \\
\hline AST (U/L) & $27.0[20.0-44.0]$ & $30.0[15.75-46.0]$ & 0.848 \\
\hline Albumin (g/L) & $30.31 \pm 8.13$ & $31.60 \pm 5.32$ & 0.589 \\
\hline Protein $(\mathrm{g} / \mathrm{L})$ & $57.16 \pm 6.69$ & $59.52 \pm 8.64$ & 0.478 \\
\hline Magnesium (mg/dL) & $1.99 \pm 0.29$ & $2.16 \pm 0.45$ & 0.315 \\
\hline $\mathrm{Ca}(\mathrm{mg} / \mathrm{dL})$ & $8.25 \pm 0.48$ & $8.61 \pm 0.63$ & 0.139 \\
\hline $\mathrm{Na}(\mathrm{mmol} / \mathrm{L})$ & $137.50 \pm 8.45$ & $138.41 \pm 5.72$ & 0.716 \\
\hline $\mathrm{K}(\mathrm{mmol} / \mathrm{L})$ & $4.65 \pm 0.91$ & $4.36 \pm 0.72$ & 0.359 \\
\hline
\end{tabular}




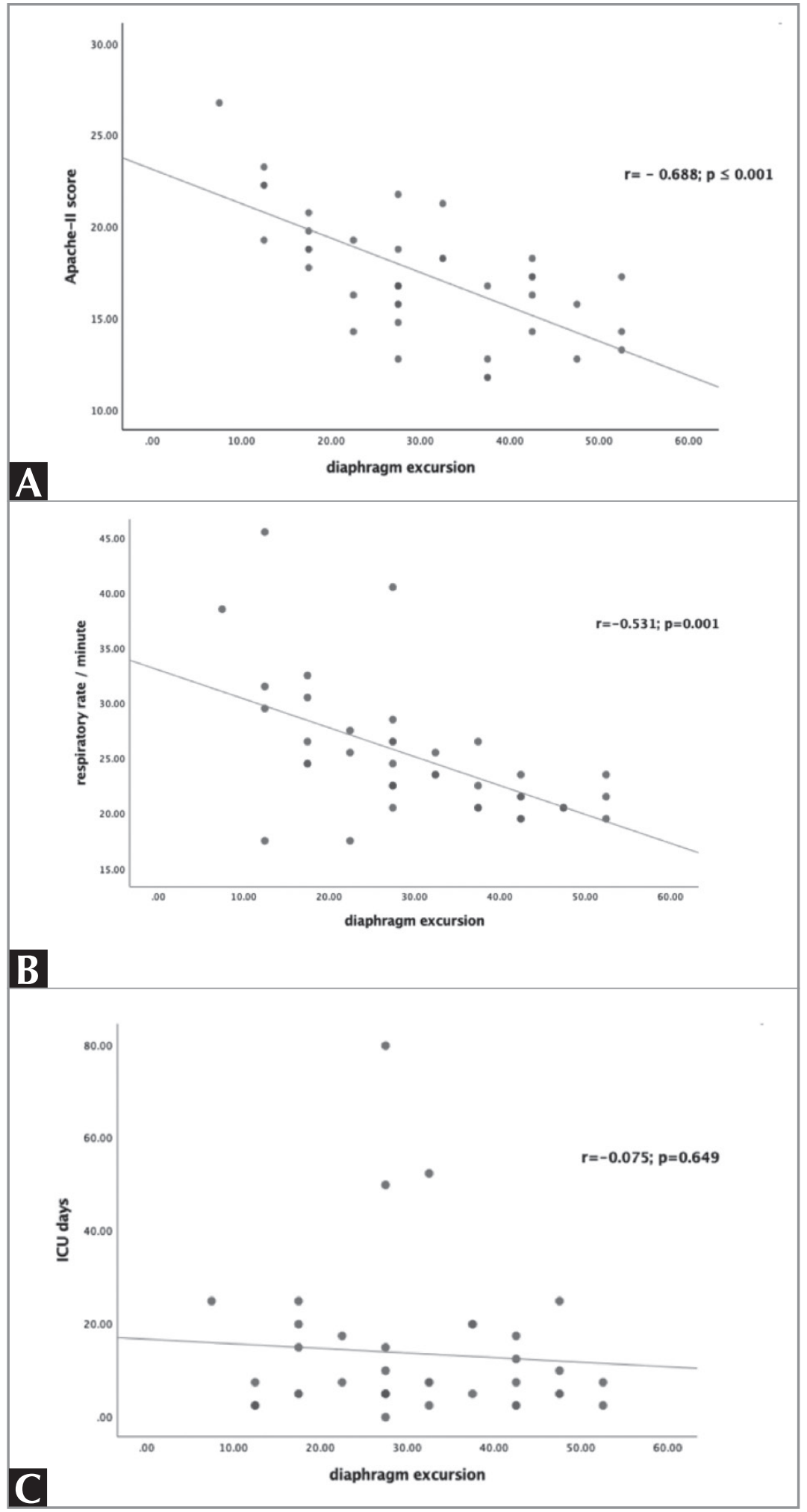

Figure 4. A. Correlation between Dex in mm and APACHE-Il scores of patients on the first day of ICU admission, B. Correlation between Dex in $\mathrm{mm}$ and respiratory rate of patients on the first day of ICU admission, C. Correlation between Dex in $\mathrm{mm}$ and length of ICU stay in days. 
(26). Furthermore, hypoxic conditions lead to impaired utilization of oxygen, and it has a detrimental effect on the physiological role of the diaphragm as well as the skeletal muscles by decreased ATP utilization and increased cell membrane $\mathrm{Na}+/ \mathrm{K}+$ ATPase pump content $(24,25)$.

For COVID-19 pneumonia, previous studies have reported that diaphragm dysfunction findings by ultrasound could be associated with poor prognosis. Possible mechanisms are thought to be critical illness myopathy-neuropathy, ventilator-induced diaphragm dysfunction, post-infectious inflammatory neuropathy or direct neurological involvement of the SARSCoV-2 virus in these patient groups $(4,27,28)$. Theoretically, these mechanisms may also be associated with decreased diaphragmatic functions in pneumonia-related to infectious/inflammatory causes other than SARS-COV-2. On the other hand, critical illness myopathy/neuropathy or ventilator-induced diaphragm diseases is more likely for the following days of ICU stay. In this study, we evaluated diaphragm with ultrasound on the first admission day of the patients to the ICU. We think that the decreased diaphragm functions on the day of admission to the ICU in pneumonia may be related to the direct effects of the infectious agent, acute hypoxemia or hypoxia-related oxygen radicals or tissue metabolites.

Our study results have shown that respiratory support escalation rate is higher in patients with lower Dex $(<19 \mathrm{~mm})$ than in normal Dex. Previous studies have suggested Dex could be used as an index for diaphragmatic contractile activity (29). Diminished diaphragm contractions reduce the volume-generating capacity of the diaphragm, resulting in respiratory failure $(30,31)$. Consistent with this, Dex has been shown as a predictor of the success of noninvasive ventilation and weaning from IMV (32-34).

Our study has some limitations. First, the sample size was small to perform analysis to determine possible predictors for decreased diaphragm functions. Secondly, only the right hemidiaphragm excursion of patients was measured, and diaphragm thickness and thickness fractions have not been evaluated. Finally, Dex was measured immediately upon admission to the intensive care unit, but no serial measurements were taken during the follow-up ICU stay.

To conclude, Dex measured on the day of ICU admission can be used to evaluate the prognosis of patients with severe pneumonia. Also, patients with diaphragm movement measuring less than $19 \mathrm{~mm}$ should be followed more closely, as they have a high mortality risk. Studies should be planned to develop scores that determine the severity of pneumonia, in which laboratory and clinical findings are evaluated together with serial measurements and diaphragm ultrasound parameters.

Ethical Committee Approval: This study approval was obtained from Ankara University Faculty of Medicine Clinical Researches Ethical Committee.

\section{CONFLICT of INTEREST}

The authors declare that they have no conflict of interest.

\section{AUTHORSHIP CONTRIBUTIONS}

Concept/Design: AGK, MÖ

Analysis/Interpretation: AGK

Data acqusition: AGK, EBV, SNS

Writing: All of authors

Clinical Revision: All of authors

Final Approval: All of authors

\section{REFERENCES}

1. Morgan AJ, Glossop AJ. Severe community-acquired pneumonia. BJA Educ 2016; 16(5): 167-72.

2. Arabi YM, Fowler R, Hayden FG. Critical care management of adults with community-acquired severe respiratory viral infection. Intensive Care Med 2020; 46(2): 315-28.

3. Li G, Cook DJ, Thabane L, Friedrich JO, Crozier TM, Muscedere l, et al. Risk factors for mortality in patients admitted to intensive care units with pneumonia. Respir Res 2016; 17(1): 80.

4. Helmy MA, Magdy Milad L, Osman SH, Ali MA, Hasanin A. Diaphragmatic excursion: A possible key player for predicting successful weaning in patients with severe COVID-19. Anaesth Crit Care Pain Med 2021; 40(3): 100875 .

5. Jung B, Moury PH, Mahul M, de Jong A, Galia F, Prades A, et al. Diaphragmatic dysfunction in patients with ICUacquired weakness and its impact on extubation failure. Intensive Care Med 2016; 42(5): 853-61.

6. Li S, Chen Z, Yan W. Application of bedside ultrasound in predicting the outcome of weaning from mechanical ventilation in elderly patients. BMC Pulm Med. 2021;21(1):217.

7. Mojoli F, Bouhemad B, Mongodi S, Lichtenstein D. Lung Ultrasound for Critically III Patients. Am J Respir Crit Care Med 2019; 199(6): 701-14. 
8. Santana PV, Cardenas LZ, Albuquerque ALP, Carvalho CRR, Caruso P. Diaphragmatic ultrasound: a review of its methodological aspects and clinical uses. I Bras Pneumol 2020; 46(6): e20200064.

9. Sik N, Citlenbik H, Ozturk A, Yilmaz D, Duman M. Point of care diaphragm ultrasound: An objective tool to predict the severity of pneumonia and outcomes in children. Pediatr Pulmonol 2021; 56(6): 1666-72.

10. Mandell LA, Wunderink RG, Anzueto A, Bartlett JG, Campbell GD, Dean NC, et al. Infectious Diseases Society of America/American Thoracic Society consensus guidelines on the management of community-acquired pneumonia in adults. Clin Infect Dis 2007; 44 Suppl 2: S27-72.

11. Schepens T, Fard S, Goligher EC. Assessing Diaphragmatic Function. Respir Care 2020; 65(6): 807-19.

12. Umbrello M, Formenti P. Ultrasonographic Assessment of Diaphragm Function in Critically III Subjects. Respir Care 2016; 61(4): 542-55.

13. Dres M, Dube BP, Mayaux J, Delemazure J, Reuter D, Brochard L, et al. Coexistence and Impact of Limb Muscle and Diaphragm Weakness at Time of Liberation from Mechanical Ventilation in Medical Intensive Care Unit Patients. Am J Respir Crit Care Med 2017; 195(1): 57-66.

14. Demoule A, Molinari N, Jung B, Prodanovic H, Chanques G, Matecki S, et al. Patterns of diaphragm function in critically ill patients receiving prolonged mechanical ventilation: a prospective longitudinal study. Ann Intensive Care 2016; 6(1): 75

15. Mercurio G, D'Arrigo S, Moroni R, Grieco DL, Menga LS, Romano A, et al. Diaphragm thickening fraction predicts noninvasive ventilation outcome: a preliminary physiological study. Crit Care 2021; 25(1): 219.

16. Corradi F, Isirdi A, Malacarne P, Santori G, Barbieri G, Romei $C$, et al. Low diaphragm muscle mass predicts adverse outcome in patients hospitalized for COVID-19 pneumonia: an exploratory pilot study. Minerva Anestesiol 2021; 87(4): 432-8.

17. Baudouin SV. The pulmonary physician in critical care . 3: critical care management of community acquired pneumonia. Thorax 2002; 57(3): 267-71.

18. Valley TS, Sjoding MW, Ryan AM, Iwashyna TJ, Cooke CR. Association of Intensive Care Unit Admission With Mortality Among Older Patients With Pneumonia. JAMA 2015; 314(12): 1272-9.

19. Bouhemad B, Dransart-Raye O, Mojoli F, Mongodi S. Lung ultrasound for diagnosis and monitoring of ventilatorassociated pneumonia. Ann Transl Med 2018; 6(21): 418.

20. Long L, Zhao HT, Zhang ZY, Wang GY, Zhao HL. Lung ultrasound for the diagnosis of pneumonia in adults: $A$ meta-analysis. Medicine (Baltimore) 2017; 96(3): e5713.

21. Llamas-Alvarez AM, Tenza-Lozano EM, Latour-Perez J. Accuracy of Lung Ultrasonography in the Diagnosis of Pneumonia in Adults: Systematic Review and MetaAnalysis. Chest 2017; 151(2): 374-82.
22. Chavez MA, Shams N, Ellington LE, Naithani N, Gilman $R H$, Steinhoff $M C$, et al. Lung ultrasound for the diagnosis of pneumonia in adults: a systematic review and metaanalysis. Respir Res 2014; 15: 50.

23. Boczkowski J. Lung infection and the diaphragm: placing basic research in clinical perspective. Am J Respir Crit Care Med 2004; 169(6): 662-3.

24. Lewis $P, O^{\prime} H a l l o r a n ~ K D$. Diaphragm Muscle Adaptation to Sustained Hypoxia: Lessons from Animal Models with Relevance to High Altitude and Chronic Respiratory Diseases. Front Physiol 2016; 7: 623.

25. Verges S, Bachasson D, Wuyam B. Effect of acute hypoxia on respiratory muscle fatigue in healthy humans. Respir Res 2010; 11: 109.

26. O'Leary AJ, O'Halloran KD. Diaphragm muscle weakness and increased UCP-3 gene expression following acute hypoxic stress in the mouse. Respir Physiol Neurobiol 2016; 226: 76-80.

27. Patel Z, Franz CK, Bharat A, Walter JM, Wolfe LF, Koralnik IJ, et al. Diaphragm and Phrenic Nerve Ultrasound in COVID-19 Patients and Beyond: Imaging Technique, Findings, and Clinical Applications. I Ultrasound Med 2021.

28. Satici C, Aydin S, Tuna L, Koybasi G, Kosar F. Electromyographic and sonographic assessment of diaphragm dysfunction in patients who recovered from the COVID-19 pneumonia. Tuberk Toraks 2021; 69(3): 425-8.

29. Soilemezi E, Tsagourias M, Talias MA, Soteriades ES, Makrakis V, Zakynthinos E, et al. Sonographic assessment of changes in diaphragmatic kinetics induced by inspiratory resistive loading. Respirology 2013; 18(3): 468-73.

30. Shiraishi M, Higashimoto Y, Sugiya R, Mizusawa H, Takeda $Y$, Fujita S, et al. Diaphragmatic excursion correlates with exercise capacity and dynamic hyperinflation in COPD patients. ERJ Open Res 2020; 6(4).

31. Dube BP, Dres M. Diaphragm Dysfunction: Diagnostic Approaches and Management Strategies. J Clin Med 2016; 5(12).

32. Umbrello $M$, Formenti P, Longhi D, Galimberti A, Piva I, Pezzi A, et al. Diaphragm ultrasound as indicator of respiratory effort in critically ill patients undergoing assisted mechanical ventilation: a pilot clinical study. Crit Care 2015; 19: 161 .

33. Barbariol F, Deana C, Guadagnin GM, Cammarota G, Vetrugno L, Bassi F. Ultrasound diaphragmatic excursion during non-invasive ventilation in ICU: a prospective observational study. Acta Biomed 2021; 92(3): e2021269.

34. Turton P, S AL, Welters I. A narrative review of diaphragm ultrasound to predict weaning from mechanical ventilation: where are we and where are we heading? Ultrasound / 2019; 11(1): 2 . 